\title{
Adapting Ecological Modernisation to the Australian Context
}

\author{
Dr. Michael Howes \\ Griffith School of Environment \& the Urban Research Program, Griffith University, \\ Gold Coast, Australia
}

Ms. Marteena McKenzie

Bushlight, Alice Springs, Australia

Prof. Brendan Gleeson

The Urban Research Program, Griffith University, Nathan, Australia

\author{
Ms. Rowan Gray \\ Brisbane City Council, Brisbane, Australia
}

Dr. Jason Byrne

Griffith School of Environment \& the Urban Research Program, Griffith University, Gold Coast, Australia

Dr. Peter Daniels

Griffith School of Environment \& the Urban Research Program, Griffith University, Nathan, Australia

All correspondence to:

Dr. Michael Howes

Griffith School of Environment

Griffith University

Gold Coast Campus

Southport QLD 4222

AUSTRALIA

Ph: +61 (0)7 55527264

Fax: +61 (0)7 55527785

E-mail: M.Howes@griffith.edu.au

(Received 3 March 2009)

\begin{abstract}
This article uses a broad range of ecological modernisation literature to derive five core theoretical themes: technological innovation; engaging with economic imperatives; political and institutional change; transforming the role of social movements; and, discursive change. These themes are then developed into an analytical framework and adapted to suit the Australian context. The underlying argument is that while key elements of weak ecological modernisation can be found in most environmental and sustainability policies, stronger versions have more transformative potential. Care must be taken, however, in transplanting the theory from the European political and economic environment to the Australian context.
\end{abstract}

Keywords: sustainability; ecological modernisation; environmental policy; environmental planning; Australia 


\section{Adapting Ecological Modernisation to the Australian Context}

\section{Introduction}

As the end of the first decade in the new century approaches we are increasingly becoming accustomed to bad news about the environment. This is a far cry from 1992 when the governments of the world signed Agenda 21 and the Australian Labor government confidently committed the country to achieving ecologically sustainable development. This commitment was echoed in a significant body of regulation and policy by the States and Territories, including in urban and regional planning frameworks that acknowledged significant threats to sustainability (McManus, 2005). Seventeen years on, the failure to achieve these goals has deeply undermined public confidence in the ability of both government and business to address environmental problems effectively. A recent opinion poll, for example, indicted that $71 \%$ of Australians agreed with the statement that 'our politicians are failing to lead on climate change' (Climate Institute, 2007).

Over the last few decades the field of environmental politics has been a battle ground between three main discourses (or shared perceptual frameworks): administrative rationalism, neo-liberalism, and ecological modernisation (Howes, 2005). Administrative rationalism perpetuated the idea that experts within the state were best placed to deal with environmental issues. This encouraged the creation of new environmental laws, regulations and procedures in the 1960s and 1970s (Torgerson, 1990; Grant \& Papadakis, 2004). From the late 1970s this approach was challenged by the rise of neo-liberalism (in Australia, frequently referred to as 'economic rationalism') which argued that the state was interfering too much in the market and pushing it away from the efficient allocation of resources. In Australia, as in much of the developed world, this precipitated a scaling back of state institutions, deregulation, the privatisation of public assets and a shift in focus to market mechanisms (Pusey, 1991). Ecological modernisation (EM) can be understood as a third discourse that emerged as a synthesis of these two: it took the central role for government and strategic expert intervention from administrative rationalism but married it with a strong emphasis on market mechanisms that emerged from neoliberalism.

EM argues that economic growth can be decoupled from environmental harm through various technological and institutional transformations. This is a powerful theory that has been chosen for the analysis because of its strong influence over environmental policy, planning and management systems in many industrialised countries over the last two decades. EM concepts appear in a variety of guises, including international sustainable development policies such as Agenda 21 (Howes, 2005), sub-national regional strategies such as the South East Queensland Regional Plan (OUM, 2005), and municipal plans (Burton 2007). They also featured in industrial regulation and cleaner production programs, particularly in continental Europe (Mol \& Sonnenfeld, 2000; Baker 2007).

The purpose of this paper is to create a theoretical framework based on EM that can be utilized for further research into Australia's response to environmental issues such as climate change. To achieve this goal the paper is divided into two parts. The first section reviews a broad spectrum of EM literature, outlines the range of versions of the theory that have emerged, and derives five core themes: technological innovation; engaging with economic imperatives; political and institutional change; transforming the role of social movements; and, discursive change (i.e. a change in the shared perceptual framework associated with environmental issues and responses). 
Section two then demonstrates how these themes need to be modified to suit the Australian political and economic context and creates a framework for future research.

\section{The Themes of Ecological Modernisation (EM)}

EM is a label that has been attached to a broad school of thought that originally emerged from Europe (and Germany in particular) during the 1980s, most notably from the work of Martin Janicke and Joseph Huber, although some of its component ideas can be traced back as far as the late 1960s (Hajer, 1995; Weale, 1998; Mol and Sonnenfeld, 2000; Mol and Spaargaren, 2000; Huber 2000 \& 2008; Grant and Papadakis, 2004; Janicke \& Jacob 2004; Janicke, 2008). Janicke (2008, page 557) argues that EM was adopted by what he refers to as the 'Berlin School of environmental policy research' in the early 1980s. The term is not widely used outside academia but some of the ideas that it entails have been highly influential in shaping many environmental policies, plans and management systems through its links to sustainable development. The core argument of EM is that although democracy, the state and the market have gone astray, they can be restructured to make them sustainable (Christoff, 1996; Mol \& Spaargaren, 2000; Dryzek, 2005; Howes, 2005). EM argues that economic growth can be decoupled from raw material throughput, energy use and waste generation through the application of new technology and the redesign of institutions (Berger, 2001; Dryzek, 2005; Howes, 2005; Janicke \& Jacob 2004; Huber 2008; Janicke 2008).

EM presumes that economic and environmental goals need not be mutually exclusive (Gouldson \& Murphy, 1997; Curran, 2001; Janicke 2008). It assumes that well designed interventions by government do not hinder economic growth but instead stimulate new and more efficient industries (Blowers, 1997; Weale, 1998; Mol \& Sonnenfeld, 2000; Janicke \& Jacob 2004; Huber 2008; Janicke 2008). Industry reduces its costs from increased technological efficiency and both the environment and community benefit from less pollution. Governments continue to play a regulatory role but are also cast as a facilitator to assist industry in becoming more sustainable (Huber 2008). New policies are directed towards correcting market failures by improving information on the impacts of actions, imposing green tax regimes to internalise negative externalities, and pricing ecological goods and services so that they can be properly valued (Lundqvist, 2000). There is strong emphasis on retaining the key institutions of modernity (science, technology, the market, industry, and the state) but embedding ecologically-reformed economic practices within them (Berger, 2001; Huber 2008). Much of the early investigation of this theory was based on European case studies and less work has been done on applying the theory to Australia, providing an opportunity for some original research.

EM ranges from the original weak 'techno-corporatist' approach that focuses mainly on technological change as an autonomous outcome of market forces, to the strong 'reflexive' approach that encourages a deliberate and strategic political transition to an 'ecological democracy', particularly within the European context (Christoff, 1996; Dryzek, 2005). Many variants fall between these two extremes but adopt some elements from each (Fisher and Freudenberg, 2001). Table 1 outlines the key range of differences. 
Table 1: The Range of Ecological Modernisation Perspectives

\begin{tabular}{|l|c|c|}
\hline View of Environment & Weak EM & Strong EM \\
\hline Scope of Change & $\begin{array}{c}\text { Technological solutions to } \\
\text { environmental problems }\end{array}$ & $\begin{array}{c}\text { Institutional / systemic / broad } \\
\text { changes to include ecological } \\
\text { concerns }\end{array}$ \\
\hline Role of Government & $\begin{array}{c}\text { Market facilitation, } \\
\text { information dissemination, } \\
\text { minimum state intervention }\end{array}$ & $\begin{array}{c}\text { Substantial state intervention, } \\
\text { institutional restructuring, } \\
\text { reforms to economic and } \\
\text { regulatory polices, and } \\
\text { internalisation of externalities }\end{array}$ \\
\hline Policy Approach & Instrumental & Communicative \\
\hline Style & $\begin{array}{c}\text { Technocratic / closed } \\
\text { decision-making by } \\
\text { economic \& political elites }\end{array}$ & $\begin{array}{c}\text { Deliberative democratic / } \\
\text { open, with participation \& } \\
\text { involvement }\end{array}$ \\
\hline Scale of Focus & $\begin{array}{c}\text { National focus on } \\
\text { developed nations }\end{array}$ & International \\
\hline EM Strategy & Hegemonic & $\begin{array}{c}\text { Diversifying, multiple } \\
\text { possibilities with EM } \\
\text { providing orientation }\end{array}$ \\
\hline
\end{tabular}

Source: Adapted from: Christoff (1996); Gibbs (2000); and Gray (2005).

The differences between the strong and weak versions can be illustrated by reviewing five core themes in EM programs for social change:

(1) Technological innovation (which plays a substantial role in both the strong and weak versions);

(2) Engaging with economic imperatives (in both strong and weak versions);

(3) Political and institutional change (modest in the weak version, substantial in the strong);

(4) Transforming the role of social movements (in the strong version); and,

(5) Discursive change (an essential aspect of the strong version but more mild in the weak version).

These themes have recurred in various guises in a number of analyses (and have been adapted here from Berger et al, 2001 and Welford and Hills, 2003).

\subsection{Technological Innovation}

EM reconstructs the view of science and technology as both a cause and a solution for environmental problems. The key focus is on encouraging technical innovation that will make industry sustainable by both preventing and curing environmental damage (Fisher and Freudenberg 2001; Cohen, 2006; Huber 2008). Innovative technologies are intended to be incorporated from as early as possible in the design phase of industrial development rather than added on as end-of-pipe measures (Welford and Hills, 2003). Technological development is intended to reduce industrial emissions (e.g. carbon dioxide, methane, nitrous oxide etc.) at the source and encourage more efficient use of resources (Berger, et. al. 2001). These innovations may be achieved "by substituting polluting materials to more environmentally friendly alternatives; increasing the efficiency of material use through waste minimisation and recycling, 
and changing the composition of output by moving away from products that are material intensive to those causing less damage to the environment" (Welford and Hills, 2003, page 325). Huber (2008) argues that national governments play a key role in encouraging the creation of lead markets that are technologically innovative and encourage others to follow. This includes promoting renewable energy and low emission technology, eliminating hazardous chemicals, substituting bio-fuels, etc. Such technological changes have to move beyond simple efficiency gains to make both production and consumption consistent with the functioning of ecosystems (Huber 2000). This focus on technology in the early incarnations of EM has been criticised for ignoring broader social and political issues (Berger, et. al. 2001; Baker 2007) but the stronger versions of EM that developed later take up this point to some extent (Mol, 1999).

\subsection{Engaging with Economic Imperatives}

The economic imperative of EM offers a vital role for markets and economic agents as conduits of ecological restructuring and reform (Gouldson \& Murphy, 1997; Mol, 2000; Mol and Sonnenfeld, 2000; Mol and Spaargaren, 2000; Seippel, 2000; Berger, et. al. 2001; Huber 2008). Proponents consider that a healthy environment is necessary for economic gain, and entrepreneurial agents are important catalysts for ecological remediation (Seippel, 2000; Fisher and Freudenberg, 2001). Market advantages are gained through achieving the highest possible environmental standards in an ecologically modernised economy (Berger, et. al. 2001; Huber 2008). The recommendations of the Garnaut (2008) report on a greenhouse gas emissions trading system for Australia are a good example.

There are key roles for producers, customers, consumers, financial institutions and insurance companies as agents of change in the pursuit of an ecologically modernised economy (Mol, 1999; Welford and Hills, 2003; Huber 2008). The economic imperatives of EM may be achieved through structural changes to the market (Welford and Hills, 2003) as well as a coherent regulatory regime set by national governments using economic prompts and performance standards (Huber 2008). Moreover, the agents of ecological reform are not motivated by altruism, rather they are "driven or influenced by tight legislation, environmental awareness and protest, and changing economic cost-benefit relations" (Berger, et. al. 2001, page 60). Hajer (1995), Mol and Spaaragren (2000) and Dryzek (1987 \& 1992) have gone further and argued that ecological rationality could replace economic rationality in the design of the institutions that shape production and governance. The idea is to hardwire the environment into decision making.

Again the weaker versions of EM have been criticised for overemphasising economic issues and neglecting social concerns (Berger, et. al. 2001). This issue has been addressed to some extent by the stronger EM versions that emerged in the 1990s (Mol, 1999; Fisher \& Freudenberg, 2001).

\subsection{Political and Institutional Change}

Although political institutions have contributed to poor environmental outcomes in the past, weak versions of EM argue that they can be readily reformed to better address ecological issues (Gouldson \& Murphy, 1997; Mol, 2000; Mol \& Sonnenfeld, 2000; Mol \& Spaargaren, 2000; Janicke \& Jacob 2004; Janicke 2008). Proponents hope that through marginal shifts in focus, political actors could be responsible for 
"building new and different coalitions to make environmental protection politically feasible" (Fisher \& Freudenberg, 2001, page 702; see also Berger, et. al. 2001). There are similarities between this version of EM, the idea of Natural Capitalism that emerged in the USA in the early 1990s (AtKisson 1999; Hawken, et. al. 1999; Hargroves \& Smith, 2005), the subsequent ideas of Industrial Ecology and Biomimicry (Huber 2000), Al Gore's (1992) notion of a Global Marshal Plan, and more recently Lester Brown's Plan B 3.0 (2008). The US literature, however, tends to focus more narrowly on the micro-level behaviour of individual firms and neglects the role of the state.

Strong EM argues for a more substantial transformation towards decentralised, consensual forms of governance, and a focus on new forms of political intervention (Spaargaren, 1997). Advocates consider the role of the nation-state to be central to achieving more sustainable societies (Christoff, 1996; Buttel, 2000; Mol \& Sonnenfeld, 2000; York \& Rosa, 2003; Janicke \& Jacob 2004; Janicke 2008). There is a focus on "open, democratic decision-making, maximising participatory opportunities for broader social interests" (Berger, et. al. 2001, page 62). These opportunities will only occur alongside increasing activism by non-governmental organisations, economic agents and changes to the institutional structure of society (Fisher \& Freudenberg, 2001). For industry, this political shift means less hierarchical command-and-control measures, more self-regulation, and an increasing use of market mechanisms (Berger, et. al. 2001).

Strong EM also advocates greater public disclosure and community participation in decision making (Mol 1999). Devotees argue that globalisation and new international market dynamics have shifted the away from traditional top-down influences of supranational bodies towards greater emphasis on the sub-national level. This regional and local focus is in line with increasing prominence of local initiatives such as Local Agenda 21 programs (Environment Australia 1999; Berger, et. al. 2001; Janicke 2008). In strong EM, the government takes the role of "contextual steering" and policy-making changes from "curative and reactive to preventative" (Berger, et. al. 2001, page 59). While international agreements can set the broad policy goal of sustainable development, it is regional planning and changes to management systems in local businesses that translate these goals into real changes on the ground (Janicke \& Jacob 2004; Janicke 2008). Janicke and Jacob (2004, page 30) cast the nation state in the role of a "local hero" that mediates between the local economy and globalised markets to protect the environment and promote eco-efficiency. Their argument is supported by Huber ( $2000 \& 2008)$.

In its more extreme form, strong EM is so dramatically different from its industrial capitalist starting point that it may well warrant "relabeling" of the dominant economic system. Many authors have pointed to similarities between strong EM and eco-philosophies such as ecological democracy (e.g. Dryzek, 1997), and others noted its potential as a transition strategy (e.g. Gleeson, 2006).

\subsection{Transforming the Role of Social Movements}

Transforming the role of social movements with increased power afforded to them in public and private decision-making is a significant part of the overall political changes required for strong EM (Mol, 2000; Mol \& Sonnenfeld, 2000). These changes entail a more inclusive form of EM, where social justice and equity issues are more cogently articulated (Fisher \& Freudenberg, 2001). The idea is to build social feedback mechanisms into the institutions of power that better link decision-makers to the 
community. This should enable problems to be quickly identified and brought to the attention of managers and policy makers. It should also make them more responsive to community concerns (Hajer, 1995).

This is where strong EM starts to overlap with the proposals offered by contemporary theories such as the Risk Society, The Third Way, and Ecological Democracy (Beck, 1992; Dryzek, 1987 \& 1992; Giddens, 1998; Mol, 1999). Mol and Spaargaren (2000), for instance, argue that strong EM and risk society theory can be grouped together under the umbrella of Reflexive Modernisation. The concept of Reflexive Modernisation is, however, a complex one and it is not possible to do it justice in the space available. An example of how the idea can be applied to the analysis of social movements can be found in Howes (2001).

Proponents of these kinds of reforms, however, admit that in bringing "outsider" groups such as social movements into the institutions of power they risk becoming co-opted and may lose some of their ability to provide useful critiques (Dryzek, 1992). Dryzek, et. al. (2003) argue that this is the case in Norway where environmental groups have had a long history of participation in major environmental policy making forums. The design challenge, therefore, is to restructure the institutions of power in such a way that they provide a pathway for community feedback without blunting the capacity of civil society to generate more radical criticisms and original thinking.

\subsection{Discursive Change}

Significant discursive change is a hallmark of strong EM because it rejects the binary opposition of economic and environmental interests (Gouldson \& Murphy, 1997; Mol, 2000; Mol \& Sonnenfeld, 2000; Mol \& Spaargaren, 2000). Furthermore, major changes in discursive practices are considered essential, where ecological principles are seen as the required policy goal of both institutions and businesses (Gouldson \& Murphy, 1997; Mol \& Sonnenfeld, 2000). The essential idea underlying strong EM is that diverse and profound changes to society's institutional structure and economic system will result in "making them more responsive to ecological concerns" (Berger, et. al. 2001, page 62). In turn, businesses can reap the benefits that better technology and better informed decision-making can bring through increased efficiency and profit as well as reduced waste, lower raw material costs, and reduced energy use per unit of production. "Conceptualizing political-economic-ecological development in diverse and open-ended terms, such that there is no single correct or accepted view of what ecological modernization must entail but multiple possibilities to which ecological modernization provides an orientation" (Berger, et. al. 2001, page 62).

EM shares much in common with the notion of sustainable development that transformed the thinking of decision makers in the 1990s by linking technical, economic, social, political and ecological issues into a package that required an integrated response (Howes, 2005). Some theorists argue that ecological modernisation underpins sustainable development policies (Huber 2000; Curran, 2001; Howes 2005). Others see sustainability as a related but broader concept because it is has a stronger social justice element that puts the emphasis on meeting the needs of the poor, future generations and other species (WCED, 1990; Langhelle, 2000; Baker 2007). This second view, however, is more applicable to the weak version of EM rather than the strong. Early programs based on EM did retain something of the Eurocentric and corporatist social consensus foundations on which it was built by requiring collaboration between government, business and the community, as well as 
a strong economy and the capacity to invest in change (Christoff, 1996; Berger, et. al. 2001; Mol \& Sonnenfeld, 2000; York \& Rosa, 2003; Davidson \& MacKendrick, 2004). The theory has evolved, however, and more recent variants may have the potential to be useful in other social and political contexts, albeit with some modifications (Mol, 1999). There remains, however, a strong European flavour in EM that results from its mainly German theoretical origins

\subsection{EM and its Critics}

Overall, EM is a broad concept that ranges between weak and strong extremes. The weaker versions focus on autonomous technological innovation and the application of market mechanisms, while the stronger versions add notions of a substantial institutional restructuring, a renewed role for social movements and a major discursive shift to new ways of thinking about environmental issues and responses. Arguably, EM has three main strengths. First, it invites an integrated approach to environmental issues by conceptually linking ecological priorities with other policy areas (e.g. the focus on economic growth and development). Second, its theoretical framework feeds into the broadly accepted policy goal of sustainable development. Third, it can generate programs for change that constructively engage with the existing institutions of power.

This is not to say that EM provides a panacea for the world's ills. There are many critics of this school of thought as well as the related policies of sustainable development. These critics are drawn from both left and right of the political spectrum (see, for example: Gallopin, et. al. 1989; De La Court 1990; Lele 1991; Di Lorenzo 1993; McEachern 1993; Chatterjee \& Finger 1994; Doyle 1998; Berger, et. al. 2001; Fisher \& Freudenburg 2001; Baker 2007). They point out that neither will put an end to poverty or inequality, they will not stop violence or injustice, they are not a remedy for the ills of a postcolonial world, and they inherit many of the underlying problems of market economics, liberal democracy, and the welfare state.

Many of these limitations have been acknowledged by the proponents and originators of EM but they still see some value in the concept (Janicke \& Jacob 2004; Janicke 2008). This paper does not have the space to revisit in detail the arguments for and against EM - it would require a whole book to do justice to the debate. The point here is just to acknowledge that this dispute exists and is ongoing. What this paper argues is simply that EM has helped to place environmental issues firmly on the mainstream political agenda, it offers the opportunity to hardwire ecological feedback into economic decision making, and has the potential to buy the world more time by slowing the rate of environmental damage. It is not an end point for development nor does it provide a utopian vision for the future. It is simply a useful staging post that goes beyond business as usual and may prepare the ground for more substantial transformations. This is why EM is able to generate both a useful tool for analysis and a strategic program for action.

\section{Transplanting EM from Europe to Australia}

EM originated as a theoretical framework to explain rapidly evolving responses to environmental issues within Europe, and Germany in particular, where the theory originated (Dryzek, et. al. 2003; Grant \& Papadakis, 2004). Elements of EM can be found throughout European environmental polices, for example, in the UK, Norway and Sweden, as well as the European Union itself (Weale 1998; Mol \& Sonnenfeld 
2000; Dryzek, et. al. 2003; Howes 2005; Baker 2007; Baker \& Eckerberg 2007). The distinctly European origins beg the question of how useful, and therefore effective, it might be in the Australian context (Curran 2009). Some work has been done on the problems of transplanting EM to the USA (Schlosberg \& Rinfret 2008), China (Huan 2009), Brazil (Milanez \& Buhrs 2008) and former socialist countries such as Hungary (Gille 2004), so what about Australia? Is it similar enough to Europe to allow for EM to be transplanted with relative ease?

Australia does bear some similarities to Germany where the school of EM originated. They are both wealthy and industrialised nations with market-based economies that engage heavily in global trade (CIA World Factbook, 2007). They both have federal parliamentary political systems with well established welfare states administered by a sizeable bureaucracy. There is an active civil society in both that generates pressure groups and movements to engage with both business and the state (e.g. both have Green parties contesting elections at the State and Federal level) (Doyle \& McEachern, 2001). Nonetheless, there are key socio-economic and environmental differences between the two, some of which are summarised in table 2 below.

Table 2: Australia v. Germany - a comparison of some key national economic characteristics

\begin{tabular}{|c|c|c|}
\hline & Australia & Germany \\
\hline Land (mil. sq km) & 7.6 & 0.35 \\
\hline $\begin{array}{l}\text { Population } \\
\text { (millions) }\end{array}$ & 20.3 & 82.4 \\
\hline GDP (billion)* & 666 & 2,585 \\
\hline GDP per capita* & 32,900 & 31,400 \\
\hline $\begin{array}{c}\text { GDP by sector: } \\
\text { Agriculture } \\
\text { Industry } \\
\text { Services } \\
\end{array}$ & $\begin{array}{c}3.8 \% \\
26.2 \% \\
70 \% \\
\end{array}$ & $\begin{array}{c}0.9 \% \\
29.1 \% \\
70 \% \\
\end{array}$ \\
\hline Main industries & $\begin{array}{c}\text { mining, industrial \& } \\
\text { transportation equipment, } \\
\text { food processing chemicals, } \\
\text { steel }\end{array}$ & $\begin{array}{l}\text { iron, steel, coal, cement, } \\
\text { chemicals, machinery, } \\
\text { vehicles, machine tools } \\
\text { electronics, food, beverages, } \\
\text { shipbuilding, textiles }\end{array}$ \\
\hline Main exports & $\begin{array}{l}\text { coal, gold, meat, wool, } \\
\text { wheat, alumina, iron ore, } \\
\text { machinery and transport } \\
\text { equipment }\end{array}$ & $\begin{array}{l}\text { machinery, vehicles, } \\
\text { chemicals, metals, textiles } \\
\text { manufactures, foodstuffs }\end{array}$ \\
\hline $\begin{array}{l}\text { Key environmental } \\
\text { issues }\end{array}$ & $\begin{array}{l}\text { soil erosion, desertification, } \\
\text { soil salinity, land clearing, } \\
\text { endangered species, threats } \\
\text { to the Great Barrier Reef, } \\
\text { limited fresh water supplies }\end{array}$ & $\begin{array}{l}\text { air pollution, acid rain, water } \\
\text { pollution, hazardous waste, } \\
\text { decommissioning of nuclear } \\
\text { power stations }\end{array}$ \\
\hline
\end{tabular}

Source: CIA World Factbook, 2007 (* GDP figures expressed as US\$ adjusted for purchasing power parity. The figures are pre-global financial crisis).

Although both countries have a similar levels of GDP per capita, Germany has a much larger economy overall with a significantly greater proportion dedicated to 
industry and high technology. Australia has a larger landmass, a smaller population, and relies far more heavily on primary industries such as agriculture and mining (Papadakis, 2002; Curran, 2007; Pearse 2009). This is evident in the structural differences in exports and the key environmental issues faced by both countries. Australia exports mainly primary products and is much more concerned about 'green' issues such as endangered species, deforestation, land degradation, water scarcity, and natural resource management (Mercer \& Marden, 2006). Germany, on the other hand, exports more manufactured goods and is often more concerned with the 'brown' issues of pollution, hazardous waste and nuclear decommissioning. Australia also faces some unique issues relating to the provision of infrastructure and services to remote and indigenous settlements (McKenzie \& Howes, 2006). All of these differences have the potential to significantly alter the application of the five EM themes outlined in the previous section because they generate different opportunities and barriers to change.

In so far as technical innovation (our first major theme of EM) is concerned, clearly Australia has less capacity (both total and relative) in terms of research, development and deployment - something that could affect its ability to ecologically modernise. According to recent OECD (2007) statistics, Australia spent only US\$ 11.6 billion $^{1}$ on research and development in 2006 while Germany spent US\$ 61.7 billion (almost a third higher per capita), in addition only $51.6 \%$ of this money came from industry in Australia while 66.8\% came from industry in Germany. While there are some notable exceptions (particularly in the agricultural and mining sectors), on the whole Australian industry tends to import technology developed in other countries rather than develop its own (Howes, 2005). The relatively small population and vast distances create other problems for the deployment of new technology (McKenzie \& Howes, 2006). All these factors suggest that it will be more difficult for Australia to undertake the technical innovation advocated by EM. If the programs of EM are having an impact, however, we would expect to see a significant increase in the resources invested in research and development, particularly with regards to environment-saving technology, with an increasing proportion of money coming from industry.

Engaging economic imperatives - the second core theme - also exhibits some significant differences. The fundamental idea of EM is to restructure the market in such a way as to create economic incentives to reduce raw material and energy use, wean the economy off non-renewable resources, and cut waste. The problem for Australia is that a large part of its production and export earnings come from the extractive industries that mine and refine non-renewable resources, particularly coal, gold, alumina, and iron ore (see table 2) and they are strongly supported by government policies (Mercer \& Marden, 2005; Howard, 2006a; Australian Government, 2008; Pearse 2009). Ecologically modernising the Australian and global economy, however, would necessitate creating economic incentives to reduce the nation's dependence on these commodities (i.e. by adopting conservation measures, replacing fossil fuels with renewable energy sources, increasing the recycling of metals, and switching to renewable materials where possible) (Hawken, et. al. 1999; Welford and Hills, 2003; Hargroves \& Smith, 2005; Howes, 2005). European economies like Germany are not as heavily dependent on these sectors (Curran, 2007). This makes the introduction of economic incentives designed to move production away from these commodities more difficult in Australia (Australian

\footnotetext{
${ }^{1}$ Measured as US\$ purchasing power parity.
} 
Government, 2007; Pearse 2009). If EM programs are having an impact we should see a shift in financial incentives, such as subsidies, away from the extractive sectors and towards renewable energy and materials. We should also witness the introduction of taxes and charges that attempt to internalise the environmental damage done by the production and use of these products. The impact of these changes should be an increase in investment in industries like material recycling, renewable energy and organic agriculture (Daniels 1992).

Political and institutional change, the third major theme, means moving government beyond the role of a basic regulator and into the role of a facilitator that helps business and the community to become more sustainable (Christoff, 1996; Buttel, 2000; Mol \& Sonnenfeld, 2000; York \& Rosa, 2003). The main proposal is to shift towards decentralised, consultative and collaborative forms of government (Spaargaren, 1997). While many Australian local governments have adopted the formal community consultative processes of Local Agenda 21 there is still fierce competition for development projects that often reduces the influence of public consultations (Howes, 2005). Research into the uptake of renewable energy systems in remote Australia, for example, found that limited community engagement was a key barrier to the uptake of new technology (McKenzie \& Howes, 2006). In terms of decentralisation, state governments have been willing to devolve responsibility to local councils but are less inclined to grant them the necessary powers and resources (Liebrecht \& Howes 2006). Between 1996 and 2007 the Howard national government moved in the opposite direction, however, by cutting funding to troublesome environmental groups (Kennedy, 2005) and taking responsibility for major environmental issues away from local and regional governments (such as the management of the Murray-Darling river basin) (Joint Press Conference, 2007). Since 1997 the new Rudd Labor government in Australia has continued to selectively centralize some powers but has also engaged in an extensive array of public consultations on a range of policy issues. One of the most prominent was the Prime Minister's Australia 2020 Summit held in April 2008 that covered issues such as: productivity; the economy; sustainability and climate change; rural Australia; health; communities and families; indigenous people; creative arts; governance; and, Australia's future in the world (Davis 2008). Another was the year long process to develop a national greenhouse gas emissions trading system, with several reports and analyses released for public comment. Interestingly the final policy white paper appears to have been far more heavily influenced by primary industries than environment groups, with very low interim targets being set and large amounts of compensation offered to businesses (Australian Government 2008). If strong EM programs are operating we would expect to see a shift of powers and resources from the national government to collaborative projects at the local and regional level, with an accompanying rise in community engagement.

In terms of the fourth theme, transforming the role of social movements, Germany has a more corporatist political culture where major policy decisions are taken by tripartite negotiations between the government, business and labour. Further, the national parliament (the Bundestag) operates on a proportional representation system that enabled the Greens and Social Democratic Parties to form the coalition national government from 1998 to 2006 (Doyle \& McEacherm, 2001; Dryzek, et al 2003). This has recently given social movements a reasonably strong ability to influence major policies as insiders in the process. Australian political culture is far less corporatist. There was a corporate-like consultation process (involving government, business, labour and the environment movement) that produced the 
National Strategy for Ecologically Sustainable Development (ESD) in 1992, but this was an unusual event and such exercises have been rare, particularly during the conservative national government 1996-2007 (Howes, 2005; Mercer \& Marden, 2006). In Tasmania the Greens held the balance of power and supported a minority Labor government 1989-92, but they have not had the same level of success in the national parliament as their German counterparts. In part this is due to the electoral system for the House of Representatives which is not proportional representation (Doyle \& McEachern, 2001; Howes, 2005). (Since the 2007 election, however, the Greens, together with two independents, hold the balance of power in the senate and the Rudd Labor government has had to negotiate with them to get several bills passed.) Evidence for strong EM programs would therefore include the deployment of more ESD-like public consultation forums, the implementation of decisions taken by these forums, and increased collaboration between the Greens and major parties.

The final theme of the strong EM program is that of discursive change. This is where the mindset of business, government and the community is modified to ensure that:

(1) Environmental issues are no longer constructed as "jobs versus the environment" (i.e. where either a project goes ahead and the environment is damaged, or the environment is protected and the jobs that would have been created by the project are lost);

(2) Governments no longer fear that intervening to protect the environment will be bad for economic growth;

(3) Businesses see good environmental management and community engagement as being good for profits (i.e. the "win-win" scenario);

(4) The community is willing to change its consumption patterns to reduce raw material use and waste (Howes, 2005).

The adoption of sustainable development as a policy goal by governments, businesses and community organisations around the world is evidence of at least a rhetorical shift towards EM but finding ways to achieve changes on the ground has proved difficult (Howes, 2005). In Australia there has been a shift even amongst the most recalcitrant conservative political leaders to a grudging acceptance of the importance of environmental issues and governments have adopted several programs to promote cleaner production and eco-efficiency in industry (Hargroves \& Smith, 2005). The total amount of resources committed to such programs, however, remains very low by international standards (Howes, 2005; Mercer \& Marden, 2006). A recent survey of managers in Australian mining firms that had adopted the ISO14000 environmental management system found that there was some belief in the business benefits of eco-efficiency, but this did not translate to an acceptance of the discourse of strong EM or greater community engagement (Farebrother, 2004).

Further, recent work by Gray (2005), measuring household metabolism in South-East Queensland, suggested that resource use is beyond what may be considered sustainable, and while some policy attempts have been made to redress this problem (such as encouragement of 'green' shopping bags and compact fluorescent light bulbs), but these initiatives remain isolated. To be effective, an integrated response is required: one that considers how each stage of the economic cycle - resource extraction, production, household consumption and waste management - contribute to the total environmental impact of household consumption (as originally suggested by the OECD 2002). (An integrated response that covers both production and consumption has been anticipated by one of the founders of EM theory, Huber (2000), in his proposal of ecological consistency.) Other research 
indicates a decline in the proportion of the public concerned about environmental issues from $75 \%$ to $57 \%$ in the period 1992-2004 (Mercer \& Marden, 2006, page 197). As the global economic crisis takes hold environmental concerns may slip further down the list of priorities.

Overall, Australia is starting from a low baseline with regards to the necessary discursive changes for strong EM. If strong EM were to occur it would manifest in three main ways:

(1) A change in the nature of the political debate (shifting away from "jobs versus environment" in particular);

(2) A willingness of industry to move beyond simple environmental management systems (to embrace more voluntary programs and community engagement); and,

(3) Significant changes to household consumption patterns (and voting).

The ultimate goal of all these program themes is to decouple economic growth from raw material use and waste. In the Australian context, Picton and Daniels (1999) examined production and consumption trends for seven major environmentallysignificant material and energy indicators between 1970 and 1996. They found that promising ecological restructuring effects based on trends in intensity of use (per unit GDP) in the 1980s were very limited in view of relatively high population growth and economic growth in the 1990s. A study by Walker (2002) of the Australian electricity, transport and agricultural sectors found some patchy and weak decoupling at the micro-level, but little evidence of a major shift to EM (either strong or weak) at the national level. There have been some promising signs in terms of pollution with significant reductions in airborne lead, carbon monoxide, ozone, oxides of nitrogen, and particulate matter declining significantly over the last three decades despite considerable economic growth. Even so, Australia is nowhere near sustainable development (Howes, 2005). York and Rosa (2003) found that for most OECD countries such improvements are more likely due to the movement of industry to developing countries so that when international trade is included the calculation of total ecological footprint for developed countries has not decreased.

\section{Conclusion}

EM argues that economic growth can be decoupled from environmental damage by adopting better technology and improving decision making structures. It is a broad school of thought with associated programs for change that range from weak technocentric approaches through to strong reflexive versions. There is a great deal of overlap with sustainable development and EM ideas have been highly influential in continental European environmental decision making.

Five core themes of strong EM have been identified: technological innovation; engaging with economic imperatives; political and institutional change; transforming the role of social movements; and, discursive change. These themes provide both and analytical framework and the basis for a program of action.

EM can be used to generate an integrated approach to environmental issues and has the advantage of supporting programs that engage with the existing institutions of power. It was, however, developed within a continental European context which has some significant differences to the Australian situation. In this country less is invested in technological research, the economy is more reliant on raw material extraction, there is less of a corporatist approach to politics, environment groups have had fewer opportunities to participate in national policy making, and the discourse of "jobs versus environment" remains stronger. Adapting EM to the 
Australian situation, either as an analytical tool or as a program for action, will therefore require some care.

\section{Acknowledgements}

The authors would like to acknowledge the support of the Urban Research Program and Griffith University. Part of this research was funded by a Griffith University Research Grant. The authors would also like to thank the anonymous reviewers of this article for their feedback. All errors and omissions remain our own. An earlier version of this paper appeared as an Urban Research Program research paper (number 23) in March 2009.

\section{Notes on contributors}

Dr Michael Howes is a senior lecturer at the Griffith School of Environment and convenes the Urban Research Program's Group on Ecological Modernisation and Sustainability (GEMS).

Ms Marteena McKenzie is a Regional Manager for Bushlight.

Prof Brendan Gleeson is the Director of the Urban Research Program.

Ms Rowan Gray works with the sustainability section of the Brisbane City Council.

Dr Jason Byrne is a lecturer with the Griffith School of Environment, and an adjunct associate professor with the Department of Regional and Urban Planning, Zhejiang University, China.

Dr Peter Daniels is a senior lecturer with the Griffith School of Environment as well as a member of GEMS and the Urban Research Program.

\section{References}

Australian Broadcasting Corporation. 2007. PM refuses to set target for carbon emissions. ABC News. Available from: http://abc.net.au/news/newsitems/200704/s1896685.htm

Australian Bureau of Statistics. 1998. Australian System of National Accounts. Canberra: Australian Bureau of Statistics. Available from: http://www.ausstats.abs.gov.au/ausstats/subscriber.nsf/0/CA2568A90021A807C A25688800207D34/\$File/52040_1997-98.pdf

Australian Bureau of Statistics. 2007a. Greenhouse Gas Emissions and Climate Change. Australian Year Book 2007. Canberra: Australian Bureau of Statistics. Available from:

http://www.abs.gov.au/AUSSTATS/abs@.nsf/bb8db737e2af84b8ca2571780015 701e/727C6AF30EAA428DCA2572360006A829?opendocument

Australian Bureau of Statistics. 2007b. Key National Indicators 2007. Canberra: Australian Bureau of Statistics. Available from: http://www.abs.gov.au/AUSSTATS/abs@.nsf/ProductsbyCatalogue/D5B5CF81 909801FFCA2572A50016FEA7?OpenDocument

Australian Government. 2008. Carbon Pollution Reduction Scheme: Australia's Low Pollution Future. Canberra: Government White Paper.

AtKisson A. 1999. Believing Cassandra: An Optimist Looks at a Pessimist's World. Melbourne: Scribe. 
Baker, S. 2007. Sustainable development as Symbolic Commitment: Declaratory Politics and the Seductive Appeal of Ecological Modernisation in the European Union. Environmental Politics 16(2): 297-317.

Baker, S. \& K. Eckerberg. 2007. Governance for Sustainable Development in Sweden: The Experience of the Local Investment Programme. Local Environment 12(4): 325-342.

Bakers C. 2005. Contemporary Australia: Sydney or the Bush? Monash University: National Centre for Australian Studies. Available from: http://www.radioaustralia.net.au/australia/pdf/sydney_bush.pdf

Berger G, Flynn A, Hines F, Johns R. 2001. Ecological Modernization as a Basis for Environmental Policy: Current Environmental Discourse and Policy and the Implications on Environmental Supply Chain Management. Innovation 14(1): 55-72

Blowers A. 1997. Environmental Policy: Ecological Modernisation or Risk Society? Urban Studies. 34(5-6): 845-871

Brown L. 2008. Plan B 3.0: Mobilizing to Save Civilization. New York: Norton. Bulkeley H. 2001. No regrets? Economy and environment in Australia's domestic climate change policy process. Global Environmental Change: 155-169

Burton D. 2007. Evaluating Climate Change Mitigation Strategies in South East Queensland. Research Paper 11. Brisbane: Urban Research Program. Griffith University. Available from: www.griffith.edu.au/centre/urp

Buttel F. 2000. Ecological Modernization as social theory. Geoforum. 31:57-65

Chatterjee, P. \& M. Finger. 2004. The Earth Brokers: Power, Politics and World Development. London; Routledge.

Christoff, P. 2005. Policy Autism or Double-Edged Dismissiveness? Australia's climate policy under the Howard government. Global Change, Peace and Security. 17(1):29-44

Christoff, P. 1996. Ecological Modernisation, Ecological Modernities. Environmental Politics. 5(3): 476-500

Climate Institute. 2007. Leadership on Climate Change a Vote Changer. Canberra. Available from:

http://www.climateinstitute.org.au/cia1/downloads/280307\%20Leadership\%20P olling\%20Media\%20Release.pdf

Cohen J. 2006. The Greenhouse Mafia. Four Corners. ABC documentary. Available from: http://www.abc.net.au/4corners/content/2006/s1568867.htm

Cohen M. 2006. Ecological Modernization and its discontents: The American environmental movement's resistance to an innovation-driven future. Futures 38:528-547

Curran, G. 2009. Ecological Modernisation and Climate Change in Australia. Environmental Politics 18(2): 201-217.

Curran G. 2007. Doing Ecological Modernisation in Australia: The Climate Policy Challenge. Paper presented to the Political Studies Association Annual Conference. 11-13 April. England: University of Bath.

Curran G. 2001. The Third Way and Ecological Modernisation. Contemporary Politics. 7(1): 41-55

Daly H. 1993. Introduction to Essays toward a Steady State Economy. In Valuing the Earth: Economics, Ecology and Ethics. Eds H Daly and K Townsend. Cambridge: MIT Press: 11-47

Daniels P. 1992. Barriers to Sustainable Development in Natural Resource-based Economies. Society and Natural Resources. 5:247-262 
Davidson D, MacKendrick N. 2004. All Dressed up with Nowhere to Go: The Discourse of Ecological Modernization in Alberta, Canada. The Canadian Review of Sociology and Anthropology. 41(1):47-65

Davis G. (convenor) 2008. Australia 2020 Summit - Final Report. Canberra:

Department of Prime Minister and Cabinet. Available from:

http://www.australia2020.gov.au/docs/final_report/2020_summit_report_full.do $\underline{\mathrm{c}}$

De La Court, T. 1990. Beyond Brundtland: Green Development in the 1990s. London: Zed Books.

DiLorenzo, T. 1993. The Mirage of Sustainable Development. The Futurist.

September-October: 14-19

Dryzek J. 2005. The Politics of the Earth: Environmental Discourses. Oxford: Oxford University Press.

Dryzek J. 1992. Ecology and Discursive Democracy: Beyond Liberal Capitalism and the Administrative State. Capitalism, Nature, Socialism 3(2):18-24

Dryzek, J. 1987. Rational Ecology: Environment and Political Economy. Oxford: Blackwell.

Dryzek J, Downes D, Hunold C, Schlosberg D, Hernes H K. 2003. Green States and Social Movements: Environmentalism in the United States, United Kingdom, Germany, and Norway. Oxford: Oxford University Press.

Doyle, T. 1998. Sustainable Development and Agenda 21: the secular bible of global free markets and pluralist democracy. Third World Quarterly. 19(4):771-786.

Doyle T, McEachern D. 2001. Environment and Politics. London: Routledge.

Environment Australia. 1999 Our community Our Future: A Guide to Local Agenda 21. Canberra: Commonwealth of Australia. Available from: http://www.environment.gov.au/esd/la21/manual/pubs/manual.pdf

Farebrother G. 2004 The role of corporate environmental management systems in micro-economic processes of ecological modernisation in Australia. [Masters Thesis] Brisbane: Australian School of Environmental Studies, Griffith University.

Fisher D, Freudenburg W. 2001. Ecological Modernisation and Its Critics: Assessing the Past and Looking Toward the Future. Society and Natural Resources. 14:701-709

Gallopin, G., P. Gutman \& H. Maletta. 1989. Global impoverishment, sustainable development and the environment: a conceptual approach. International Social Science Journal. 41(August):375-397.

Gille, Z. 2004. Europeanising Hungarian Waste Policies: Progress or Regression. Environmental Politics 13(1): 114-134.

Gibbs D. 2000. Ecological Modernisation, regional economic development and regional development agencies. Geoforum. 31:9-19

Giddens A. 1998. The Third Way: The Renewal of Social Democracy. Cambridge: Polity Press.

Gleeson B. 2006. Australian Heartlands: Making Space for Hope in the Suburbs. Sydney: Allen and Unwin.

Gore A. 1992. Earth in the Balance: Ecology and the human spirit. Boston: Houghton Mifflin.

Gouldson A. Murphy J. 1997. Ecological Modernization: Restructuring Industrial Economics. In Greening the Millennium? The New Politics of the Environment Ed M Jacobs. Oxford: Blackwell Publishers: 74-86 
Grant R, Papadakis E. 2004. Challenges for global environmental diplomacy in Australia and the European union. Australian Journal of International Affairs. 58(2):279-292

Gray R. 2005. Household metabolism and Sustainability: a methodology for assessing the environmental resource demands of South-East Queensland households. [Honours Thesis] Brisbane: Australian School of Environmental Studies, Griffith University.

Hargroves K, Smith M. (eds). 2005. The Natural Advantage of Nations: Business Opportunities, Innovation and Governance in the 21st Century. London: Earthscan.

Hajer M. 1995. The Politics of Environmental Discourse: Ecological Modernization and the Policy Process. Oxoford: Clarendon Press

Hawken P, Lovins A, Lovins H. 1999. Natural Capitalism: Creating the Next Industrial Revolution. Boston: Little Brown \& Co.

Holmes J. 2007. Earth, Wind and Fire. Fours Corners. Sydney: ABC. Available from: http://www.abc.net.au/4corners/content/2007/s1898635.htm

Howard J. 2006a. Transcript of the Prime Minister the Hon John Howard MP Address at the Business Council of Australia Annual Dinner. 13 November 2006. Sydney: Wentworth. Available from: http://www.pm.gov.au/News/speeches/speech2246.html

Howard J, Downer A, MacFarlaine I, Campbell I. 2006b. Asia-Pacific Partnership Sets New Path to Address Climate Change. Joint Press Release. January 12. Canberra: Office of Prime Minister. Available from: http://www.pm.gov.au/media/Release/2006/media_Release1743.cfm

Howard J, Downer A, Turnbull M. 2007. Australia to lead the world: Global initiative on forests and climate. Canberra: Joint Press Release. Available from: http://www.environment.gov.au/minister/env/2007/pubs/mr29mar07.pdf

Howes M. 2005. Politics and the Environment: Risk and the Role of Government and Industry London: Earthscan

Howes, M. 2001. Globalisation and Environmental Protest. Policy, Organisation \& Society 20(2): 77-96.

Huan, Q. 2007. Ecological Modernisation: A realistic green road for China? Environmental Politics 16(4): 683-687.

Huber, J. 2000. Towards Industrial Ecology: Sustainable development as a Concept of Ecological Modernization. Journal of Environmental Policy \& Planning. 2:269285.

Huber, J. 2008. Pioneering countries and the global diffusion of environmental innovations: These from the viewpoint of ecological modernisation theory. Global Environmental Change. 18:360-367.

Janicke, M. 2008. Ecological Modernisation: new perspectives. Journal of Cleaner Production. 16:557-565.

Janicke, M. \& K. Jacob. 2004. Lead Markets for Environmental innovations: A New Role for the Nation State. Global Environmental Politics. 4(1):29-46.

Jones D. 2003. Trading for climate without trading off on the environment: an Australian perspective on integration between emissions trading and other environmental objectives and programs. Climate Policy. 3(2):125-141

Kelly P. 2007. Spreading the faith. The Australian. 31 March. Available from: http://theaustralian.news.com.au/story/0,20867,21476846$\underline{28737,00 . h t m l ? \text { from }=\text { public_rss }}$ 
Kennedy J. 2005. Environment groups angered by funding cuts. ABC Radio. 11 April. Available from: http://www.abc.net.au/am/content/2005/s1342435.htm

Kent A, Mercer D. 2006. Australia's mandatory renewable energy target (MRET): an assessment. Energy Policy 34: 1046-1062

Langhelle O. 2000. Why Ecological modernization and Sustainable Development should not be Conflated. Journal of Environmental Policy \& Planning. 2:303322

Lele, S. 1991. Sustainable Development: A Critical Review. World Development. 19(6):607-621.

Liebrecht T, Howes M. 2006. Collaboration: a solution to inter-jurisdictional strife? Paper presented at the Governments and Communities in Partnership Conference. Centre for Public Policy. 25-27 September. University of Melbourne

Lundqvist L. 2000. Capacity-building or social construction? Explaining Sweden's shift towards ecological modernisation. Geoforum 31:21-32

McEachern, D. 1993. Before and Beyond Ecologically Sustainable Development: The Process and Limits to the Government's Response to Environmental Concerns. Paper presented to the Australasian Political Studies Association Annual Conference September 29 - October 3. Melbourne: Monash University.

McGee J, Taplin R. 2006. The Asia-Pacific Partnership of Clean Development and Climate: A Complement or Competitor to the Kyoto Protocol? Global Change, Peace \& Security. 18(3):173-192

McKenzie M, Howes M. 2006. Remote Renewable Energy in Australia: Barriers to Uptake and the Community Engagement Imperative. Paper presented at the Australasian Political Studies Association Annual Conference. 25-27 September. University of Newcastle

McManus P. 2005. Vortex Cities to Sustainable Cities: Australia's urban challenge. Sydney: UNSW Press

Medail F, Quezel P. 1998. Biodiversity Hotspots in the Mediterranean Basin: Setting Global Conservation Priorities. Conservation Biology. 13(6):1510-1513

Mercer D, Christesen L, Buxton M. 2007. Squandering the future-Climate change, policy failure and the water crisis in Australia. Futures 39:272-287

Mercer D Marden P. 2006. Ecologically Sustainable Development in a 'Quarry' Economy: One Step Forward, Two Steps Back. Geographical Research. June. 44(2):183-203

Milanez, B. \& T. Buhrs.2008. Ecological Modernisation Beyond Western Europe: The Case of Brazil. Environmental Politics 17(5): 784-803.

Mol A. 2000. The Environmental Movement in an era of Ecological Modernisation. Geoforum. 31:45-56

Mol A, Sonnenfeld D. 2000. Ecological Modernisation Around the World: An Introduction. Environmental Politics. 9(1):3-14

Mol A, Spaargaren G. 2000. Ecological Modernisation. Environmental Politics. 9(1): $17-49$

OUM. 2005. South East Queensland Regional Plan. Office of Urban Management. Brisbane: Queensland Government. Available from: http://www.oum.qld.gov.au/?ID=29

OECD. 2007. Main Science and Technology Indicators 2006-2. Paris: Organisation for Economic Cooperation and Development. Available from: http://www.oecd.org/dataoecd/49/45/24236156.pdf 
OECD. 2002. Policies to Promote Sustainable Consumption: An Overview. Paris: Organisation for Economic Cooperation and Development

Papadakis E. 2002. Global Environmental Diplomacy: Australia's stances on global warming. Australian Journal of International Affairs. 56(2): 265-277

Pearse, G. 2009. Quarry Vision: Coal, climate change, and the end of the resources boom. Quarterly Essay 33: 1-122.

Picton T, Daniels, P. 1999. Ecological restructuring for sustainable development. Ecological Economics. 29:405-425

Pusey M. 1991. Economic Rationalism in Canberra: A Nation Building State Changes its Mind. Sydney: Cambridge University Press.

Riedy C, Diesendorf M. 2003. Financial subsidies to the Australian fossil fuel industry. Energy Policy. 31:125 - 137

Seippel O. 2000. Ecological Modernization as a Theoretical Device: Strengths and Weaknesses. Journal of Environmental Policy and Planning. 2:287-302

Spaargaren G. 2003. Sustainable Consumption: A Theoretical and Environmental Policy Perspective. Society \& Natural Resources. 16(8):687-701

Torgerson D. 1990. Limits of the Administrative Mind: The problem of Defining Environmental Problems. In Managing Leviathan: Environmental Politics and the Administrative State. Eds R Paehlke, D Torgerson. London: Bellhaven Press:115-161

Walker S. 2002. A Search for the Occurrence of Ecological Modernisation in Australia. [Honours Thesis] Brisbane: Australian School of Environmental Studies, Griffith University

Joint Press Conference. 2007. Water Summit. February 23. Available from: http://www.pm.gov.au/media/interview/2007/Interview24163.cfm

Weale A. 1998. The Politics of Ecological Modernization. In Debating the Earth: The Environmental Politics Reader. Eds J Dryzek, D Schlosberg Oxford: Oxford University Press: 301 - 318

Welford R, Hills P. 2004. Ecological Modernisation, environmental policy and innovation priorities for the Asia-Pacific Region. International Journal of Environment and Sustainable Development. 2(3):324-340

York R, Rosa E. 2003. Key Challenges to Ecological Modernization Theory. Organisation and Environment. 16(3):273-288 